\title{
EVALUATION OF THE EFFECT OF HEDGEROW INTERCROPPING USING Leucaena leucocephala AND FERTILIZER APPLICATION ON GROWTH AND YIELD OF GARDEN EGGS (Solanim melongena)
}

\author{
T.F.G. Insaidoo ${ }^{1}$ and S.J. Quarshie-Sam ${ }^{2}$ \\ ${ }^{1}$ Oduom Methodist Church, Kumasi. \\ Formerly at Centre for Biodiversity Utilization and Development (CBUD), \\ Kwame Nkrumah University of Science and Technology, Kumasi \\ ${ }^{2}$ Department of Agroforestry, \\ Kwame Nkrumah University of Science and Technology, Kumasi
}

\begin{abstract}
Field trials were conducted in Ghana to assess the effect of applying Leucaena prunings as mulch and N.P.K., 15-15-15 compound fertilizer on the growth and yield of garden eggs (Solanum melongena) during the 1993 minor and 1994 major cropping seasons. The crop was grown with or without Leucaena mulch as well as $0 \mathrm{~kg} / \mathrm{ha}, 180 \mathrm{~kg} / \mathrm{ha}$ and $360 \mathrm{~kg} / \mathrm{ha}$ rates of fertilizer. The crop responded very well to the 15-15-15 compound fertilizer used, since plants without fertilizer had significantly reduced height; more days to flowering, fruiting and harvesting and produced yields far below the potential yield levels of the crop. In both seasons, applying the Leucaena mulch increased the mean yield by 21 percent over the no mulch treatments. Economic analysis of the various treatments showed that: producing the crop during the minor season with rainfall was not profitable; producing the crop during the major season was profitable when the half rate of fertilizer, mulched $\left(F_{1} M_{1}\right)$; full rate fertilizer, mulched $\left(F_{2} M_{1}\right)$ and full rate fertilizer no mulch $\left(F_{2} M_{0}\right)$ treatments were applied, with the $F_{1} M_{1}$ ranking first as the most profitable option. This was shown by the comparative net income per hectare of: $\phi 1,215,000, \phi 1,201,020$ and $\phi 819,020$ for the $\left(F_{1} M_{1}\right),\left(F_{2} M_{1}\right)$ and $\left(F_{2} M_{0}\right)$ respectively. Producing garden eggs with Leucaena mulch in hedgerow intercropping could reduce fertilizer requirement, at least by half. Hedgerow intercropping with garden eggs is therefore profitable and may become an attractive alternative to small-scale farmers as prices of inorganic fertilizer continue to increase over the years.
\end{abstract}

Keywords: Leucaena mulch, 15-15-15 fertilizer, applications, hedgerow intercropping, Solanum melongena.

\section{INTRODUCTION}

Garden eggs (Solanum melongena) is a fruit vegetable, which forms an important nutrient source in the daily diet of most West Africans
(Sinnadurai, 1992). In Ghana, garden eggs is among the major vegetables sold at the market. The consumption of the crop is on the increase in developing countries like Ghana, due to increas-

64 Journal of Science and Technology, Volume 27 no. 2, August, 2007 
ing human population and better understanding of the nutrient values of the crop in the human diet.

Successful and increased production of vegetables rely greatly on the use of fertilizers; and garden eggs particularly has been identified to respond very well to commercial fertilizers as well as good amount of organic manure for good yield. Extensive dependence on chemical fertilizers for increased production of gardens eggs may not always be feasible in many developing countries, especially countries in Africa due to increasing cost of fertilizers and low income of rural farmers. Also, extensive use of agricultural chemicals, including fertilizers can pose risks to human health and to the environment (Quatara et al., 1991).

To increase the production of garden eggs therefore, it is important to develop management practices that would lead to increased soil fertility and decreasing the extent of dependence on chemical fertilizers. Mulching with organic materials, among others, has the advantage of increasing the fertility levels of the soil through the supply of nutrient elements when the organic materials decompose. The most convenient way of obtaining mulch materials is by growing multi-purpose trees that produce a great deal of organic matter inside the field or by growing the crop in alley cropping (hedgerow intercropping) systems. Most studies with alley cropping have dealt with field crops (Palada et al., 1992). In order to understand the principles and importance of the production of garden eggs in agroforestry (alley cropping) systems, it became necessary to evaluate/assess the performance of garden eggs growing in hedgerows of Leucaena leucocephala.

\section{MATERIALS AND METHODS}

\section{Study Area and components of the study}

The study was in two parts:

i) Laboratory Analysis on determination of dry matter yield and nutrient content of prunings and soil at the site. This was undertaken at the Soil Research Institute (SRI), Kumasi ii) Field trials, which formed the main studies consisted of the production of the intercrop (garden eggs) at the Research farm of the Institute of Renewable Natural Resources (IRNR), KNUST, Kumasi. The field trials were conducted in the September - November 1993 minor season and repeated in the April - July 1994 major rainy season.

\section{Soil and plant analysis}

The studies began with chemical analysis of the surface soil (0-15cm depth) at the site. At the end of the second field trials, representative soil samples were taken at the $0-15 \mathrm{~cm}$ depth, for end of cropping soil analysis. The soil samples taken before and at the end of the experiment were airdried and analyzed for soil $\mathrm{pH}$, organic Carbon, total $\mathrm{N}, \mathrm{P}_{2} \mathrm{O}_{5}, \mathrm{~K}_{2} \mathrm{O}, \mathrm{Ca}$ and $\mathrm{Mg}$ content of the soil.

During each of the three biomass harvests (cuttings) in each of the two cropping seasons, three Leucaena leaf samples were collected from each of the prunings. These leaf samples were oven-dried at $60^{\circ} \mathrm{C}$ until they attained constant weight and analyzed for $\mathrm{N}, \mathrm{P}, \mathrm{K}, \mathrm{Ca}$ and $\mathrm{Mg}$ content of the leaf (plant). All the soil and plant analysis were carried out in duplicates at the Soil Research Institute (SRI) at Kwadaso - Kumasi.

\section{Size of field of Study}

The intercrop was planted in Leucaena leucocephala hedgerows planted at $4 \mathrm{~m}$ inter-hedgerow and $0.25 \mathrm{~m}$ intra-hedgerow spacing. Seedlings of the local cultivars of the garden eggs were planted at $0.95 \mathrm{~m}$ inter-row and $0.90 \mathrm{~m}$ intra-row spacing.

\section{Design and Treatments}

The experiment was replicated three times, and one replicate or block covered two alleys (hedgerows) with the size of $16 \mathrm{~m} \mathrm{x} 8 \mathrm{~m}$. The treatments within the blocks were set in a splitplot design, with the fertilizer application as the main-plot treatment and mulch application as the sub-plot treatment. Main-plot and sub-plot sizes were $8 \mathrm{~m} \times 5 \mathrm{~m}$ and $5 \mathrm{~m} \times 4 \mathrm{~m}$ respectively. 
Each fertilizer treatment was applied in three split doses at 5-week intervals, with the first split application taking place at two weeks after transplanting. With 40 garden egg plants in each fertilizer treatment plot, the half rate $(180 \mathrm{~kg} / \mathrm{ha})$ and full rate $(360 \mathrm{~kg} / \mathrm{ha})$ plots received $6 \mathrm{~g}$ and $12 \mathrm{~g}$ of the 15-15-15 compound fertilizer per plant respectively, during each of the three times of fertilizer application.

There were 20 garden eggs plants in each Leucaena mulched treatment plot. The Leucaena hedgerows were cut (pruned) at $30 \mathrm{~cm}$ above ground level, three times during the period of production at 5-week intervals. The first pruning was done two weeks after transplanting the intercrop. During the first cutting, prunings were weighed and evenly spread in the entire mulched plots. In subsequent cuttings, the prunings were weighed, equally divided into 20 and applied at the base of the individual garden egg plants in mulched plots.

\section{Cultural practices}

Appropriate cultural practices carried out include manual weeding, spraying insecticides against insect pests and applying furadan and dithane to control nematodes and fungal diseases respectively.

\section{Assessment of some growth parameters of the intercrop \\ The following growth parameters of the garden eggs, planted in the various treatment plots were assessed: plant height at 60 days after transplant- ing; number of days to first and 50\% flowering; number of days to first and 50\% fruiting; and number of days to first harvest.}

\section{Assessments of yield and yield components Fruits from sampled garden eggs plants were counted and weighed at each harvesting time. Yield values recorded for the various treatment plots were totals from the total number of har- vests made during the maturity period of the intercrop. Data on yield and yield components of}

the intercrop was based on fruit size (g/fruit); number of fruits per plant; and fruit yield (tonnes/ha).

\section{Analysis of Field Data}

Data from field trials, which included growth parameters (plant height, days to $50 \%$ flowering, days to $50 \%$ fruiting and days to first harvest); yield and yield components (fruits size, number of fruits per plant, number of fruits per hectare) were analysed using the Analysis of Variance (ANOVA). Differences in treatment means were compared using the least significant difference (LSD) at 5\% level of probability.

\section{RESULTS AND DISCUSSION}

Variation in soil characteristics

The chemical properties of the surface soil (0$15 \mathrm{~cm}$ depth) at the site, at the start and end of the field trials are presented in Tables 1 and 2.

Table 1: Chemical properties of the surface soil $(0-15 \mathrm{~cm}$ depth) at the start of the trials

\begin{tabular}{lc}
\hline \multicolumn{1}{c}{ Characteristics } & Level $^{1}$ \\
\hline $\mathrm{pH}\left(\mathrm{H}_{2} \mathrm{O}\right)$ & $5.71(0.118)$ \\
Organic Carbon $(\%)$ & $1.65(0.118)$ \\
Nitrogen $(\%)$ & $0.12(0.009)$ \\
Phosphorus (ppm) & $2.58(0.225)$ \\
Potassium (ppm) & $63.50(0.707)$ \\
Calcium $(\mathrm{meq} / 100 \mathrm{~g})$ & $6.27(2.407)$ \\
Magnesium $(\mathrm{meq} / 100 \mathrm{~g})$ & $2.67(0.822)$ \\
\hline
\end{tabular}

The results indicated lack of significant change of $\mathrm{pH}, \mathrm{K}$ and $\mathrm{Mg}$ levels in the soil at the end of the trials, generally in all the treatment plots although fertilizer and mulch were applied on the respective plots. Also, there was a general decline of organic Carbon and $\mathrm{Ca}$ levels in the soil by the end of the trials. The low initial fertility level of the soil may account for the lack of significant soil improvement even in plots mulched and/or treated with fertilizer. This confirms reports on a Leucaena alley cropping trials in Zam-

66 Journal of Science and Technology, Volume 27 no. 2, August, 2007 
Table 2: Chemical properties of the surface soil $(0-15 \mathrm{~cm})$ at the end of the trials

\begin{tabular}{|c|c|c|c|c|c|c|c|}
\hline Treatment $^{\mathbf{a}}$ & $\begin{array}{c}\mathbf{p H} \\
\left(\mathrm{H}_{2} \mathrm{O}\right)\end{array}$ & $\begin{array}{c}\text { Org. C } \\
(\%)\end{array}$ & $\begin{array}{c}\mathrm{N} \\
(\%)\end{array}$ & $\begin{array}{c}\mathbf{P} \\
(\mathbf{p p m})\end{array}$ & $\begin{array}{c}\mathbf{K} \\
(\mathrm{ppm})\end{array}$ & $\begin{array}{c}\mathrm{Ca} \\
(\mathrm{meq} / \mathbf{1 0 0 g}) \\
\end{array}$ & $\begin{array}{c}\text { Mg } \\
\text { (meq/100g) } \\
\end{array}$ \\
\hline$F_{0} M_{0}$ & 6.08 & 1.25 & 0.14 & 3.50 & 63.50 & 4.00 & 1.80 \\
\hline$F_{0} M_{1}$ & 5.65 & 1.27 & 0.14 & 2.50 & 71.50 & 3.20 & 1.70 \\
\hline$F_{1} M_{0}$ & 5.97 & 1.29 & 0.17 & 5.12 & 66.50 & 4.40 & 2.20 \\
\hline$F_{1} M_{1}$ & 5.62 & 1.25 & 0.13 & 2.87 & 58.50 & 3.40 & 2.20 \\
\hline$F_{2} M_{0}$ & 5.95 & 1.34 & 0.17 & 3.50 & 56.50 & 3.20 & 3.00 \\
\hline$F_{2} M_{1}$ & 5.85 & 1.43 & 0.15 & 6.81 & 65.00 & 4.20 & 3.20 \\
\hline \multirow[t]{2}{*}{ Mean $^{b}$} & 5.85 & 1.31 & 0.15 & 4.05 & 63.58 & 3.73 & 2.32 \\
\hline & $(0.168)$ & $(0.064)$ & $(0.015)$ & (1.481) & (4.987) & $(0.442)$ & $(0.579)$ \\
\hline
\end{tabular}

a $F_{0} M_{0}=$ No fertilizer, no mulch

$F_{0} M_{1}=$ No fertilizer, mulched

$F_{1} M_{0}=180 \mathrm{~kg} / \mathrm{ha}$ (half rate) $15-15-15$ fertilizer, no mulch

$F_{1} M_{1}=180 \mathrm{~kg} / \mathrm{ha}$ (half rate) 15-15-15 fertilizer, mulched

$F_{2} M_{0}=360 \mathrm{~kg} / \mathrm{ha}$ (full rate) $15-15-15$ fertilizer, no mulch

$F_{2} M_{1}=360 \mathrm{~kg} / \mathrm{ha}$ (full rate) 15-15-15 fertilize, mulched

$b$ Standard deviations of means are given in brackets.

bia by Matthews et al., (1992), in which the authors remarked that it appears that soil improvement may occur where the soil fertility is already relatively high, but where it is low, then even further depletion occurs. The removal of the nutrient by the crop for vegetative growth and fruit formation might also contribute to the lower or constant level of nutrient elements at the end of the trials. Lal (1989b) in alley cropping trials in Nigeria found that soil organic matter, total $\mathrm{N}$, $\mathrm{pH}$ and exchangeable bases declined in all treatments, although these trends were least marked in the L. leucocephala and G. sepium alley crop treatments.
There was however a slight increase in $\mathrm{N}$ levels and a significant increase in $\mathrm{P}$ levels at the end of the trials. This was probably due to the fact that the amount of nutrients contributed by the Leucaena prunings was far more than (Table 4) the amount required by the intercrop. And after the crop and the Leucaena plant itself had made use of their requirements the excess were left in the soil. Subbiah and Sundararajan (1990) have reported that the most suitable rates of fertilizer (nutrients requirements) for yield improvement were $\mathrm{N}: \mathrm{P}_{2} \mathrm{O}_{5}: \mathrm{K}_{2} \mathrm{O}$ at 100:50:30 kg/ha for aubergines (garden eggs).

\section{Dry matter and nutrient yields from the Leu-} caena prunings

Biomass (dry matter) yield was greater with the first prunings than in subsequent prunings in both years (Table 3 ) due to the longer interval between previous cropping and the next growing

Table 3: Dry Matter (biomass) yield (ton/ha) of hedgerow prunings of L. leucocephala intercropped with garden eggs

\begin{tabular}{lccccc}
\hline \multirow{2}{*}{ Cropping season } & \multicolumn{4}{c}{ Prunings (Excluding woody stems) } \\
& $\mathbf{1}^{\text {st }}$ & $\mathbf{2}^{\text {nd }}$ & $\mathbf{3}^{\text {rd }}$ & Mean $^{*}$ & Total \\
\hline 1993 & $1.91^{\mathrm{a}}$ & $0.62^{\mathrm{c}}$ & $0.45^{\mathrm{c}}$ & $0.99(4.64)$ & 2.97 \\
1994 & $1.02^{\mathrm{b}}$ & $0.65^{\mathrm{c}}$ & $0.52^{\mathrm{c}}$ & $0.73(4.96)$ & 2.20 \\
\hline
\end{tabular}

${ }^{*}$ Values in brackets are Mean Annual Biomass Production (ton/ha)

${ }^{a}$ DM yield over a period of 32 weeks

${ }^{b}$ DM yield over a period of 18 weeks

${ }^{c}$ DM yield over a period of 5 weeks 
season, which allowed the Leucaena hedgerows to grow without disturbance.

The amount of nutrients contained or supposed to have been contributed (nutrient yield) by the L. leucocephala prunings (Table 4) were within the range of values reported in other studies (Palada et al., 1992). Assuming 20\% nutrient use efficiency of $\mathrm{N}$ from prunings as observed with maize crop (Kang, 1987), the leucaena prunings could have contributed a total of $48 \mathrm{~kg}$ N/ha in 1993 and $56 \mathrm{~kg} \mathrm{~N} /$ ha in 1994.

\section{Effect of the fertilizer and mulch on the} growth and yield of the intercrop

The relatively large quantities of nitrogen added to the soil from the L. leucocephala prunings
(Table 4) and the lack of significant change of $\mathrm{N}$ levels in the soil that received the half and full rate fertilizer, mulched treatments (Tables 1 and 2) would suggest that there was a more efficient release and uptake of $\mathrm{N}$ from these treatments. The low levels of almost all the nutrients in the soils with the half rate fertilizer, mulched treatments at the end of the trials (Table 2) can also be attributed to the efficient release of nutrients and the probable high uptake of the nutrients by the intercrop in these treatments.

In both years, plants (the intercrop) treated with full rate fertilizer, mulched, full rate fertilizer, no mulch and those treated with half rate fertilizer, mulched flowered at the same period, and were generally taller than those in the other treatments

Table 4: Nutrient yield (kg/ha/year) from L. leucocephala prunings used

\begin{tabular}{lccccc}
\hline \multirow{2}{*}{ Cropping season } & $\mathrm{N}$ & $\mathrm{P}$ & $\mathrm{K}$ & $\mathrm{Ca}$ & $\mathrm{Mg}$ \\
\hline 1993 & 238.85 & 6.49 & 85.80 & 40.81 & 14.38 \\
1994 & 279.84 & 6.95 & 91.79 & 47.14 & 14.88 \\
\hline
\end{tabular}

Table 5: Effect of fertilizer and mulch on height of crop at 60 days after transplanting, days to 50\% flowering and fruiting and days to first harvest

\begin{tabular}{lcccc}
\hline \multicolumn{1}{c}{ Treatment } & $\begin{array}{c}\text { Height } \\
\text { (cm) }\end{array}$ & $\begin{array}{c}\text { Days to 50\% } \\
\text { Flowering }\end{array}$ & $\begin{array}{c}\text { Days to 50\% } \\
\text { Fruiting }\end{array}$ & $\begin{array}{c}\text { Days to First } \\
\text { Harvest }\end{array}$ \\
\hline & & $\mathbf{1 9 9 3}$ & & \\
No fert.., no mulch & 28.0 & 82 & 90 & 85 \\
No fert., mulched & 36.7 & 68 & 79 & 82 \\
Half rate fert., no. mulch & 62.0 & 57 & 64 & 73 \\
Half rate fert., mulched & 62.3 & 56 & 61 & 74 \\
Full rate fert., no mulch & 70.0 & 56 & 62 & 72 \\
Full rate fert., mulched & 68.3 & 55 & 60 & 73 \\
LSD (5\%) & 4.7 & 1 & 4.9 & 2.2 \\
CV (\%) & 5.3 & 0.9 & 4.4 & 1.8 \\
& & & & \\
No fert.., no mulch & 32.0 & 67 & 64 & 81 \\
No fert., mulched & 57.3 & 58 & 61 & 77 \\
Half rate fert., no. mulch & 63.0 & 56 & 61 & 74 \\
Half rate fert., mulched & 71.0 & 55 & 61 & 71 \\
Full rate fert., no mulch & 61.0 & 55 & 60 & 71 \\
Full rate fert., mulched & 70.0 & 53 & 4 & 5.1 \\
LSD (5\%) & 10.3 & 2 & 4.1 & 4.2 \\
CV (\%) & 10.7 & 2.2 & & \\
\hline
\end{tabular}

68 Journal of Science and Technology, Volume 27 no. 2, August, 2007 


\begin{tabular}{|c|c|c|c|c|}
\hline \multicolumn{5}{|c|}{ ad mulch on fruit size, number of fruits and fruit yield } \\
\hline Treatment & $\begin{array}{c}\text { Fruit size } \\
\text { (g/fruit) }\end{array}$ & $\begin{array}{c}\begin{array}{l}\text { No. of Fruits/ } \\
\text { Plant }\end{array} \\
\end{array}$ & $\begin{array}{c}\text { No. of Fruits } \\
\left(10^{3} / \mathrm{ha}\right)\end{array}$ & $\begin{array}{c}\text { Fruits yield } \\
\text { (ton/ha) }\end{array}$ \\
\hline \multicolumn{5}{|c|}{1993} \\
\hline No fert.., no mulch & 28.2 & 4 & 37 & 1.0 \\
\hline No fert., mulched & 41.5 & 10 & 100 & 4.2 \\
\hline Half rate fert., no. mulch & 42.8 & 18 & 180 & 7.8 \\
\hline Half rate fert., mulched & 47.0 & 23 & 235 & 11.0 \\
\hline Full rate fert., no mulch & 47.3 & 23 & 230 & 11.0 \\
\hline Full rate fert., mulched & 50.7 & 26 & 255 & 13.2 \\
\hline $\operatorname{LSD}(5 \%)$ & 1.4 & 3.5 & 35.2 & 1.3 \\
\hline $\mathrm{CV}(\%)$ & 2.0 & 12.2 & 12.2 & 9.7 \\
\hline \multicolumn{5}{|c|}{1994} \\
\hline No fert.., no mulch & 29.4 & 17 & 163 & 4.8 \\
\hline No fert., mulched & 40.7 & 27 & 268 & 10.9 \\
\hline Half rate fert., no. mulch & 39.7 & 37 & 370 & 14.8 \\
\hline Half rate fert., mulched & 48.3 & 54 & 535 & 25.8 \\
\hline Full rate fert., no mulch & 46.7 & 42 & 422 & 19.8 \\
\hline Full rate fert., mulched & 49.4 & 53 & 530 & 26.3 \\
\hline $\operatorname{LSD}(5 \%)$ & 3.6 & 4.3 & 42.5 & 2.6 \\
\hline $\mathrm{CV}(\%)$ & 5.2 & 6.8 & 6.8 & 9.3 \\
\hline
\end{tabular}

(Table 5). Plants treated with no fertilizer, mulched were taller $(\mathrm{P}<0.05)$ and also flowered and fruited significantly earlier than those with no fertilizer plus no mulch (Table 5).

There was lack of significant difference in fruit size and yield for plants treated with the half rate fertilizer, mulched treatment and the full rate fertilizer, mulched treatments, especially when there was adequate rainfall (Table 6). This indicates the efficiency of the half rate fertilizer, mulched treatments in promoting the growth and yield of the crop. This efficiency from the $F_{1} M_{1}$ treatment is probably due to:

i) The additional moisture conserved by the mulch material

ii) The Leucaena mulch enhancing the availability of nutrient elements from the fertilizer

iii) The more efficient release of nutrient elements from the mulch material as well as from the fertilizer due to adequate amount of moisture in the soil of this treatment.

Thus, by applying the mulch with the half rate fertilizer, the mulch could substitute for the half reduction in the fertilizer.

Effect of the mulch on the growth and yield of the intercrop

In both years, the significantly greater value of the fruit size, number of fruits and fruit yield from mulched plots than those from unmulched plots (Table 7) can be attributed to the positive effect of the mulch material in promoting growth and yield of the crop. As indicated in Table 4, there were large quantities of nutrients yield from the Leucaena prunings, which could contribute to the relatively high growth and yield of the crop in mulched plots. Also, it is probable that the mulch material could conserve enough moisture for regular use by the crop, and maintained a cool soil temperature which was a fa- 
Table 7: Effect of Leucaena leucocephala mulch on fruit size, number of fruits and fruit yield of garden eggs (1993 and 1994 seasons)

\begin{tabular}{lcccc}
\hline Treatment & $\begin{array}{c}\text { Fruit size } \\
\text { (g/fruit) }\end{array}$ & $\begin{array}{c}\text { No. of Fruits/ } \\
\text { Plant }\end{array}$ & $\begin{array}{c}\text { No. of Fruits } \\
(\mathbf{1 0} / \mathbf{h a})\end{array}$ & $\begin{array}{c}\text { Fruits yield } \\
\text { (ton/ha) }\end{array}$ \\
\hline & & $\mathbf{1 9 9 3}$ & & \\
No mulch & 39.4 & 15.0 & 149.0 & 6.6 \\
Mulched & 46.4 & 20.0 & 197.0 & 9.5 \\
LSD (5\%) & 0.8 & 2.0 & 20.3 & 0.7 \\
CV (\%) & 2.0 & 12.2 & 12.5 & 9.7 \\
& & $\mathbf{1 9 9 4}$ & & \\
No mulch & 38.6 & 32.0 & 318.0 & 13.1 \\
Mulched & 46.1 & 45.0 & 444.0 & 21.0 \\
LSD (5\%) & 2.1 & 2.5 & 24.5 & 1.5 \\
CV (\%) & 5.2 & 6.8 & 6.8 & 9.3 \\
\hline
\end{tabular}

vourable condition for the root system of the crop, for a more efficient absorption of nutrient elements and water. Tindal (1983) has recommended mulching Solanum melongena to reduce high soil temperature which is injurious to the root system of the crop. The contribution of the mulch material is a positive development to $\mathrm{Ag}$ riculture in Ghana and other developing countries because the results indicate that there can be significant reduction in the dependence of chemical fertilizers, which continue to increase in prices. Therefore low-income farmers in these countries can rely on Leucaena mulch materials for improved soil fertility and increased production of vegetable crops, especially garden eggs.

Effect of the hedgerow on the growth and yield of the intercrop

During the major rainy season (1994) cropping, plants grown in the middle of the alleys were significantly taller and produced more number of fruits and higher yield than those close to the hedgerows. This was probably due to competition for nutrients and water between the garden eggs close to the hedgerows and the Leucaena hedges. Atta-Krah (1983) has observed that when the prunings were put on the surface without soil disturbance, Leucaena coppices grew vigorously and competed with the associated maize crop, and reduced its yield. Tindal (1983) has observed that exposure of the local garden eggs to full sun is necessary since shaded conditions reduce growth.

\section{Profitability of producing the intercrop with the various treatments}

Economic analysis of the data showed that during the major rainy season, treatments that received the half rate fertilizer, mulched $\left(\mathrm{F}_{1} \mathrm{M}_{1}\right)$; full rate fertilizer, mulched $\left(\mathrm{F}_{2} \mathrm{M}_{1}\right)$ and full rate fertilizer no mulch $\left(\mathrm{F}_{2} \mathrm{M}_{0}\right)$ were profitable, and the $\mathrm{F}_{1} \mathrm{M}_{1}$ ranked first. However, during the minor season, none of the combined fertilizer and mulch treatments was profitable, even though some appreciable net income per hectare were obtained for treatments that received the half and full rates fertilizer, with or without mulch (Table 8 ). The results indicate that fertilizer is a necessary requirement for economic production of the crop. However, with adequate water, the half rate fertilizer can be efficient particularly when combined with the Leuceana mulch material, which then becomes even more efficient, in promoting growth and yield than the full rate fertilizer, with or without fertilizer. The fact that the minor season (1993) cropping was not profitable for all the treatment combinations confirms the reason why farmers, especially in Ghana do not usually culti-

70 Journal of Science and Technology, Volume 27 no. 2, August, 2007 
Table 8: Comparative Economic Analysis and ranking the profitability of the combined fertilizer and mulch treatments (1993 and 1994 cropping)

\begin{tabular}{|c|c|c|c|c|c|c|}
\hline \multirow[b]{2}{*}{ Treatments } & \multicolumn{4}{|c|}{ Criteria } & \multirow[b]{2}{*}{ Profitability** } & \multirow[b]{2}{*}{ Ranking } \\
\hline & $\begin{array}{c}\text { Gross } \\
\text { Yield } \\
\text { (kg / ha) }\end{array}$ & $\begin{array}{c}\text { Total Costs } \\
\text { per ha } \\
(\mathrm{TC})^{*}\end{array}$ & $\begin{array}{l}\text { Net Income } \\
\text { per ha } \\
(\mathrm{NI})^{*}\end{array}$ & $\begin{array}{c}\text { Revenue on } \\
\text { Investment } \\
\text { (NI / TC) }\end{array}$ & & \\
\hline & \multicolumn{6}{|c|}{1993} \\
\hline No fert.., no mulch & 1,250 & 438.00 & -338.00 & -0.77 & NP (Loss) & $6^{\text {th }}$ \\
\hline No fert., mulched & 4,200 & 555.00 & -217.00 & -0.39 & NP (Loss) & $5^{\text {th }}$ \\
\hline Half rate fert., no. mulch & 11,700 & 621.00 & 315.00 & 0.50 & NP & $1^{\text {st }}$ \\
\hline Half rate fert., mulched & 11.000 & 719.00 & 161.00 & 0.22 & NP & $4^{\text {th }}$ \\
\hline Full rate fert., no mulch & 11,220 & 675.00 & 223.00 & 0.33 & NP & $3^{\text {rd }}$ \\
\hline \multirow[t]{2}{*}{ Full rate fert., mulched } & 13,200 & 773.00 & 283.00 & 0.36 & NP & $2^{\text {nd }}$ \\
\hline & \multicolumn{6}{|c|}{1994} \\
\hline No fert.., no mulch & 6,000 & 568.22 & -88.22 & -0.16 & NP (Loss) & $6^{\text {th }}$ \\
\hline No fert., mulched & 10,900 & 684.98 & 187.02 & 0.27 & NP & $5^{\text {th }}$ \\
\hline Half rate fert., no. mulch & 17,000 & 750.98 & 657.02 & 0.87 & NP & $4^{\text {th }}$ \\
\hline Half rate fert., mulched & 25,800 & 848.98 & $1,215.02$ & 1.43 & $\mathrm{P}$ & $1^{\text {st }}$ \\
\hline Full rate fert., no mulch & 20,300 & 804.98 & 819.02 & 1.02 & $\mathrm{P}$ & $3^{\text {rd }}$ \\
\hline Full rate fert., mulched & 26,300 & 902.98 & $1,201.02$ & 1.33 & $\mathrm{P}$ & $2^{\text {nd }}$ \\
\hline
\end{tabular}

* Values are in thousands of cedis (ל'000)

** NP means Non-Profitable; and P means Profitable

vate the crop on such high grounds, on commercial basis without irrigation during the minor rainy season. The results also mean that as the cost of labour and the price of fertilizer increase over the years or when there is no subsidies on fertilizer, it would be more economical for smallscale farmers to adopt the $\mathrm{F}_{1} \mathrm{M}_{1}$ treatment than the $\mathrm{F}_{2} \mathrm{M}_{1}$ treatment especially during the major rainy season. Nyambeki (1985) has observed that alley cropping appears to be a good landconserving system, but with availability of subsidies on fertilizer and herbicides the system may become less attractive.

\section{CONCLUSION}

The local garden eggs (Solanum melongena) grown responded very well to the NPK: 15-1515 fertilizer used. The Leucaena prunings applied as mulch yielded relatively large quantities of nutrients, with mean values of $259.35 \mathrm{~kg} \mathrm{~N} /$ ha, $6,72 \mathrm{~kg} \mathrm{P} / \mathrm{ha}, 88.80 \mathrm{~kg} \mathrm{~K} / \mathrm{ha}, 43.98 \mathrm{~kg} \mathrm{Ca} / \mathrm{ha}$ and $14.63 \mathrm{~kg} \mathrm{Mg} / \mathrm{ha}$ during the two cropping seasons. The relatively large quantities of nitro- gen added to the soil from the Leucaena prunings and the lack of significant change of $\mathrm{N}$ levels in the soil treated with the half rate fertilizer, mulched and full rate fertilizer, mulched treatments would suggest that there was a more efficient release and uptake of $\mathrm{N}$ from these treatments.

Applying the Leucaena mulch increased the mean yield by 21 percent over the no mulch treatments. Better growth and yield of the crop in mulched treatment plots were in part due to the significant amount of nutrients provided by the Leucaena mulch material and also the probable reduction of the soil temperature by the mulch material. During the major rainy season, the hedgerows could significantly reduce the number of fruits and fruit yield to the tune of 16 and 12 percent respectively. This was mainly due to shade effect and probable competition for nutrients and water between the garden eggs close to the hedgerows and the Leucaena hedges. 
Economic analysis of the various treatments showed that:

i) Producing the crop during the minor season with rainfall was not profitable.

ii) Producing the crop during the major rainy season was profitable when the half rate of fertilizer, mulched $\left(\mathrm{F}_{1} \mathrm{M}_{1}\right)$; full rate fertilizer, mulched $\left(\mathrm{F}_{2} \mathrm{M}_{1}\right)$ and full rate fertilizer no mulch $\left(\mathrm{F}_{2} \mathrm{M}_{0}\right)$ treatments were applied.

iii) Among the three treatments that were economical, the $\mathrm{F}_{1} \mathrm{M}_{1}$ ranked first as the most profitable option, followed by the $F_{2} M_{1}$. This was shown by the comparative net income per hectare of: $\notin 1,215,000, \notin 1,201,020$ and $\varnothing 819,020$ for the $\left(F_{1} M_{1}\right),\left(F_{2} M_{1}\right)$ and $\left(\mathrm{F}_{2} \mathrm{M}_{0}\right)$ respectively.

iv) Fertilizer is a necessary requirement for optimum growth and yield of the crop. However, with adequate rainfall (water), the half rate fertilizer can be efficient, particularly when combined with the Leuceana mulch material, which then becomes even more efficient in promoting growth and yield than the full rate fertilizer, with or without fertilizer.

The results thus indicated that producing the Solanum melongena with Leucaena leucocephala mulch in alley cropping during the major rainy season is feasible with lower inputs of fertilizer.

\section{ACKNOWLEDGEMENTS}

This Master of Science research work was produced under the sponsorship of the African Network for Agroforestry Education (ANAFE), Kenya. Unreserved thanks and gratitude goes to all who helped in this study.

\section{REFERENCES}

Atta-Krah, A.N. (1983). The weediness of Leucaena leucocephala (lam) De wit and its control in Leucaena based agroforestry system. Seminar Paper at IITA, June 17,1983 .
Brewbaker, J.T. (1987). A multipurpose tree genus for tropical agroforestry, pages 289323. In: Steppler, H.H. and P.K.R. Nair eds, Agroforestry: A Decade of Development, ICRAF, Nairobi, Kenya.

Kang, B.T. (1987). Nitrogen cycling in multiple cropping systems. In: Wilson, J.R. ed. Advances in Nitrogen cycling in Agricultural Ecosystems. PP 333-348. CAB. International, Walingford, U.K.

Lal, R. (1989b). Agroforestry systems and soil surface management of a tropical alfisol 111. Changes in soil chemical properties. Agroforestry Systems 8:113-132.

Matthews, R.B., Lungu, S., Volk,J., Holden, S.T., and. Solberg, K (1992). The potential of alley cropping in improvement of cultivation systems in the high rainfall areas of Zambia 11: Maize Production. Agroforestry Systems 17:241-261.

Nyambeki, D.S. (1985). Economic evaluation of alley cropping leucaena with maize-maize and maize-cowpea in southern Nigeria. Agricultural Systems 17:248-258.

Ouatara, S., Lupatu, M., Kilimwiko. L., Gikaru, G. and Ajaji, F., (1991). Natural Fertilizers: New life for Tire soils. African Farmer 6:21.

Palada, M.C., Kang, B.T., Claussen, S.L., (1992). Effect of alley cropping with Leucaena leucocephala and fertilizer application on yield of vegetable crops. Agroforestry Systems 19:139-147.

Sinnadurai, S. (1992). Vegetable cultivation. Asempa publishers, Accra, Ghana. 208pp.

Tindal, H.D. (1983). Solanaceae. Vegetables in the tropics. Macmillan Press, London. 533pp.

72 Journal of Science and Technology, Volume 27 no. 2, August, 2007 